\title{
リアプノフ関数を用いた電力系統の オンライン過渡安定度評価の一手法
}

\author{
正員平 良 栄 吉 (三菱央機) \\ 正員 宮 城 隼, 夫 (疏球大学) \\ 正員山下勝 巳 (琉球大学)
}

\section{A Method of Transient Stability Estimation for Power Systems by Lyapunov Function}

Eikichi Taira, Member (Mitsubishi Electric Corp.), Hayao Miyagi, Member, Katsumi Yamashita, Member (Ryukyu University)

The power system stability problem has been one of the major subjects concerning power system engineering, and is becoming much more significant today in accordance with increasing size and complexity of interconnected power systems. In this problem, it is well known that the direct method of Lyapunov is the most suitable method of on-line transient stability estimation for power systems, and several different techniques have been proposed for the construction of Lyapunov functions up to this time. However, the effectiveness of these Lyapunov functions for power systems have been demonstrated using only digital computer simulations.

The purpose of this paper is to construct microprocessor-based on-line transient stability estimation system using Lyapunov function constructed by the Lagrange-Charpit method and estimate the transient stability of a microalternator connected to a large system. The experimental results show that this system can act satisfactorily for estimating the transient stability of the power system.

\section{キーワード : 電力系統, リアプノフ関数,オンライン過渡安定度評価, 位相差測定,オイラー法による予測}

\section{1.まえがき}

電力系統は需要の增大に伴い年々巨大化・複雑化し てきているが，最近はこれに加えて公害問題など社会 情整からの制約のため, 取得できる電源用地や送電ル 一トも限定され電源の大容量化・遠隔化の傾向も避け がたい情勢になってきている。このため，少数の大容 量発央所と送電線による大容量長距離送電を余儀なく され，系統計画あるいは系統運用の段階において，系 統安定度に関する問題が一層重要性を增すようになっ てきている。

電力系統の過渡安定度解析に対する手法としては, 一般に次の二つに分類することができる。一つは故障 発生瞬時から故障回線遮断に至るまての動摇状態をス
テップバイステップに解き，系統の最終形態が安定を 保持するように臨界故障除去時間を得る方法である。 そのためには，故障継続時間を想定してシステムの最 終形態㔖入後の発電機の動きを長時間にわたって調查 し安定・不安定を判別する必要があるうえ，計算打切 りの是非についてもかなりの経験と適切な判断が要求 される。この方法に対し，系統の安定性をある評価関 数との相対関係を通して判定するという方法がある。 リアプノフの直接法はこれに類するもので, 系統の最 終形態へ突入するまでの過嬑状態を求め, 最終形態乫 入瞬時における各状態量を把暒するだけてその後の系 統の動向を知ることができ，計算時間の大幅な短縮が 図れると同時に計算打切りによる唄判定を回避するこ とができる。 
電力系統におけるリアプノフ関数構成法としては,

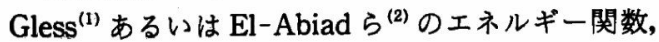
Siddiqe $^{(3)}$ による物理的概念に基づく構成法，また Zubov の偏微分方程式を解く構成法, 特に, Yu ら ${ }^{(4)}$

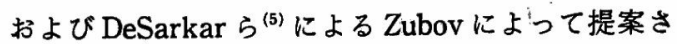
れた級数解の近似解を用いる方法が挙げられる。更 に, $\mathrm{Pai}^{\left({ }^{(6)}\right.}$ らによって提案されたリアプノフ関数ある いはその時間導関数などの形式をあらかじめ未定係数 含みで仮定し, 関数のもつべき性質を制約条件として 係数選定を行い構成する方法, また著者らによって提 案されたラグランジュ・シャルピ法を基盤とする構成 法(7)などが挙げられる。しかしながら,これらの関 数の有効性の検証については計算機シミュレーション により行われるものがほとんどで, 実機モデルへ適用 しその関数の有効性を検証した論文は著者らが知ると ころでは見当らない。実際, リアプノフ関数を用いて 実機モデルのオンライン過渡安定度評価を行うには次 の二つの大きな問題が生じる。

（1）リアプノフ関数を評価するのに状態変数を測 定しなければならないが，特に十分な測定精度をもつ。 位相差測定装置を構筑しなければならない。

（2）リアプノフ関数を計算するのに必要な処理時 間抽よび遮断器を動作させるのに必要な動作時間が存 在するので, これらの時間遅れを十分考慮しなければ ならない。

本論文では, 電力系統のオンライン過渡安定度評価 を行うため位相差測定装置を構築しその有効性を検証 すると共に, リアプノフ関数を計算するのに必要な処 理時間扝よび遮断器を動作させるのに必要な動作時間 の遅れを補正するため, オイラー法によるリアプノフ 関数の予測值を算出し過渡安定度評価に適用する。ま た, 計算機シミュレーション結果と実験室の小形機に よる実験結果との比較検証を行うことにより本方式の 有効性を示している。

\section{2. オンライン過渡安定度評価システム}

本実験に使用したシステムの全景を図 1 に，また提 案するオンライン過渡安定度評価システムの概要図を 図 2 に示している。図 2 に示すように, 一機-無限大 母線系統が本実験室の小形機を含む模擬電力系統によ り構成されている。小形機は, $5.5 \mathrm{~kW}$ の直流電動機 および $3 \mathrm{~kW}$ の交流発電機で構成され, 直流電動機に より交流電動機が駆動される。また，直流電動機の速 度制御については直流電動機の端子電圧をサイリスタ 制御することにより行われる。このとき，交流発電機 と無限大母線を示すシステム (沖縄電力).とが 100

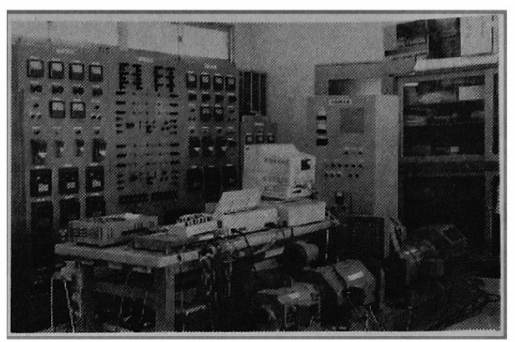

図 1 本システムの全景

Fig. 1. A photograph of the whole system.

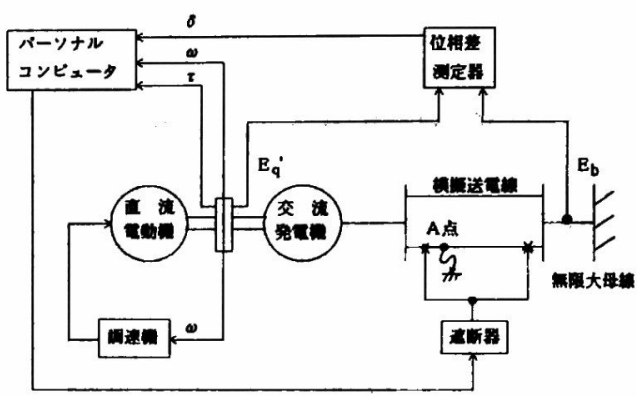

図 2.オンライン過渡安定度評価システム

Fig. 2. On-line transient stability estimation system.

$\mathrm{km}$ 模擬した二回線送電線を通じて連系されている。 ここでは, 二回線送電線の一回線上 $A$ 点において, すなわち, 発電機母線端から全長の四分の一地点に三 相短絡故障を想定し, この故障回線の除去をリアプ， フ関数を用いて自動的に行うものである。その際，リ アノフ関数を評価するのに状態量として位相差 $\delta$, 速 度 $\omega$ および機械的入力 $\Delta P_{m}$ を観測する必要がある。 速度については直流タコジェネレータの出力量を, ま た機械的入力についてはトルクメータの出力量 $\tau$ の 観測値を利用し，位相差については十分な測定精度を もつ位相差測定回路を構築することによりその出力量 を利用する。なお, リアプノフ関数の計算には, 16 ビットマイクロプロセッサi 80286 を内藏したパーソ ナルコンピュータ PC-9801 VX 41 を用いている。

$\langle 2 \cdot 1\rangle$ 位相差測定装置の構築 内部誘起電圧 $E_{Q}^{\prime}$ と無限大母線電圧 $E_{b}$ 間の位相差 $\delta$ を測定するには, $E_{q}{ }^{\prime}$ と $E_{b}$ の電圧波形をそれぞれ測定しなければなら ないが， $E_{q}{ }^{\prime}$ は仮想電圧であるため利用することはて きない。ここでは， $E_{q}^{\prime}$ と同位相の電圧波形を得るた め, 回転軸に交流発電機と同極数をもつ交流タコジェ ネレータ(ACTG)を取付けその出力電圧を利用する。 このとき, ACTG と $E_{b}$ との電圧波形を図示すると 


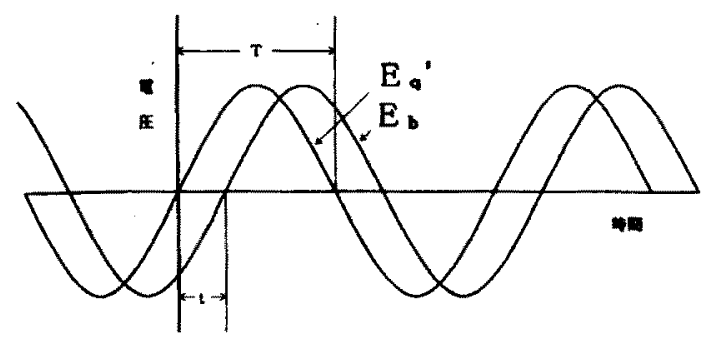

図 3 位相 差

Fig. 3. Phase angle.

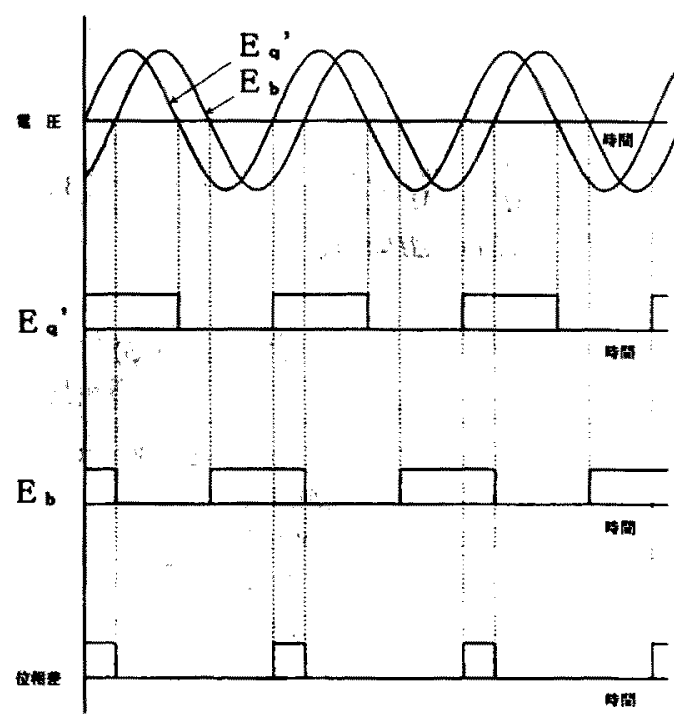

図 4 波形整形

Fig. 4. Wave arrengement.

図3のようになるが，便宜上こここては ACTGの出 力電圧を $E_{q}^{\prime}$ と記述している。図 3 から明らかなよ に， $E_{q}^{\prime}$ の電圧を基準波としその半周期を $T$ ，また $E_{a}^{\prime}$ と $E_{b}$ 間の時間差を $t$ とすると位相差 $\delta$ は次式て 与えられる。

$$
\delta=180 \frac{t}{T} \quad(\mathrm{deg})
$$

それのえ，図4のように $E_{q}^{\prime}$ の正の半波と $E_{b}$ の負の 半波をそれぞ矩形波に整形し，また，この二つの絽 形波をAND ゲートに通すことにより $E_{q}{ }^{\prime} と E_{b}$ との 位相差部を得ることができる。なお，位相差には図 5 に示すようにE゙に対して進みと遅れが存在するが, $E_{q}^{\prime}$ と位相差部の立上りを観測することにより位相の

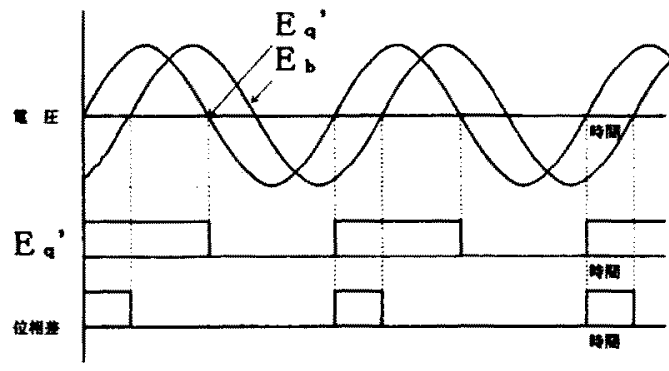

(a) 位㮩㜊办

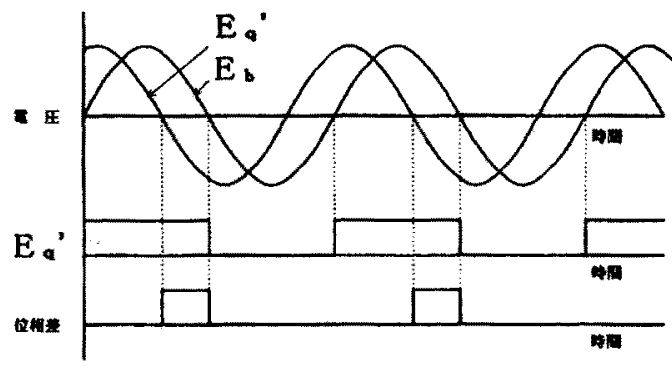

(b) 位相進み

図 5 基準波に対する進みと遅れ

Fig. 5. Lagging phase and Leading phase.

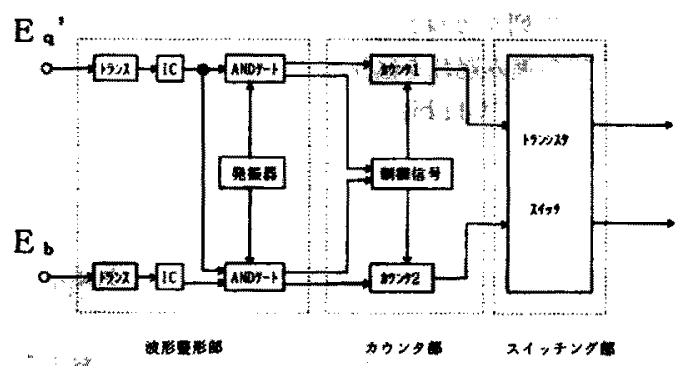

图 6 位相差測定装置の输成図

Fig. 6. Block diagram of phase angle detector.

進みと漣れを判断することができる。图 6 には，提案 する位相差測定装置の構成図を示す。本装置は波形整 形部，カウンタ部およびスイッチング部の 3 部分から 構成されている。まず，波形整形部ては $E_{q}^{\prime}$ と $E_{b}$ の 電圧のグランドレベルが異なるため変圧器を用いて絶 緑と降圧を行い，IC(TCA 780)で波形を矩形波に整 形する。また，発振回路から得られるパルス列を基準 波と位相差部に加える。次に，カウンタ部では波形整 形部で得られたパルス列をカウントするカウンタとそ 


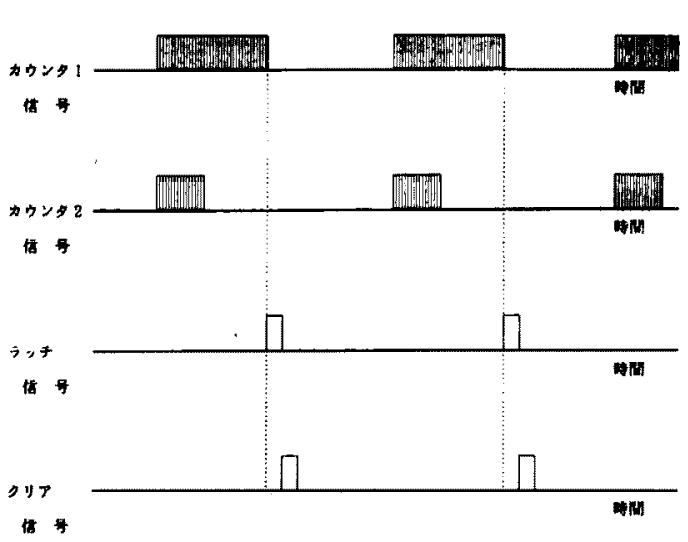

困 7 カウンタ信号および制御信号

Fig. 7. Counter and control signals.

表 1 三相電源の位相差

Table 1. Phase angle of three phase power source.

\begin{tabular}{c|c|c|c|c|c|c}
\hline 真 值 (deg) & 180.0 & 120.0 & 60.0 & 0.0 & -60.0 & -120.0 \\
\hline 測定值 (deg) & 179.8 & 120.2 & 60.0 & 0.0 & -59.5 & -119.7 \\
\hline
\end{tabular}

の值をラッチおよびクリアする制御信号生成部からで きており，その夕イムチャートは図 7 となる。なお， カウンタは 12 bit の二進カウワタではあるが，位相差 部のパルス列をカウントするカウンタ 2 の最上位 bit は，位相の進み遅れを区別する符号 bitとして用いる ため，実際には 11 bit カウンタとして使用する。更 に，スイッチング部ではパーソナルコンピュータの保 護のためホトカプラを用いた絶縁形のディジタルイン タフェースカードを取付けているので, カウンタ出力 のTTLレベルを昇圧するためのトランジスタスイッ チ回路を設けている。

上記で示したように波形整形部，カウンタ部および スイッチング部を構成し，更にカウンタ部の出力をパ ーソナルコンピュータに取込むことにより位相差を次 式のように求めることがてきる。

$$
\delta=180 \frac{n_{2}}{n_{1}} \quad(\mathrm{deg})
$$

ただし， $n_{1}$ :カウンタ 1 のカウント数, $n_{2}$ : カウンタ 2 のカウント数

図 6 に示す位相考湘定装置の有効性を検証するた め, 三相電源の線間電圧を測定したのでその結果を表 1 に示す。表 1 から明らかなように，本装置により測 定された位相差は真值との愦差が 0.5 度以下であるこ とから，位相差測定装置として十分な測定精度をもっ ていることがわかる。
表 2 システムパラメータと定格値

Table 2. System parameters and rated values.

\begin{tabular}{cc|cc}
\hline$S_{B}$ & $3.0 \mathrm{~kW}$ & $E_{a}^{\prime}$ & $1.298 \mathrm{pu}$ \\
\hline$V_{B}$ & $220 \mathrm{~V}$ & $E_{b}$ & $0.9545 \mathrm{pu}$ \\
\hline$I_{B}$ & $7.8 \mathrm{~A}$ & $X_{d}^{\prime}$ & $0.59 \mathrm{pu}$ \\
\hline$Z_{B}$ & $16.28 \Omega$ & $\dot{Z}_{b}$ & $0.0344+j 0.181 \mathrm{pu}$ \\
\hline$M$ & $6.67 \mathrm{sec}$ & $T_{b}$ & $0.0731 \mathrm{~s}$ \\
\hline$D$ & $9.84 \mathrm{pu}$ & $K_{\theta}$ & $0.1927 \mathrm{pu}$ \\
\hline
\end{tabular}

〈2・2〉 システム方程式とシステムバラメータ

電力系統の動特性式は, 故障前, 故障中および故降 除去後（最終形態）とでその記述が異なるが,ここて はリアプノフ関数の構成上必要な最終形態の動特性式 のみを記述する。

$$
\left.\begin{array}{l}
\dot{\delta}=\omega \\
\dot{\omega}=-\frac{D}{M} \omega-\frac{\omega_{0}}{M}\left[P_{e}(\delta)-P_{m}\right] \\
\Delta \dot{P}_{m}=\left\{K_{g} \omega-\Delta P_{m}\right\} / T_{g}
\end{array}\right\}
$$
たたし，

$$
P_{e}(\delta)=\frac{E_{q}^{\prime 2}}{Z} \cos \phi+\frac{E_{q}^{\prime} E_{b}}{Z} \cos (\delta+\psi)
$$

であり， $Z$ および $\phi$ は直軸過渡りアクタンス $X_{d}^{\prime}$ と 線路インピーダンス $\dot{Z}_{1}$ との和のインピーダンスの大 きさとインピーダンス角を意味する。

模擬電力系統の各パラメータおよび定格值について は表 2 に示す。 $S_{B}, V_{B}$ および $I_{B}$ は，それぞれ発電機 の定格容量, 定格電圧および定格電流であり， $Z_{B}$ は 基準インピーダンスである。なお，他の諸記号の詳細 な説明については付録に示す。

\section{〈2・3〉 リアプノフ関数棈成とその予測法}

リアプノフの直接法によれば，系統の最終形態突入 時に场ける各状態量を把握するだけて，その後の系統 の安定判別を行える利点がある。それゆえ、リアプノ フの直接法は, 電力系統のオンライン過渡安定度語価 に最も適した手法と考えられる。電力系統に対するり アプノフ関数構成法には、これまて種々の方法が提案 されているが,ここでは, ラグランジュ・シャルピ法 に基づくリアプノフ関数 ${ }^{(7)}$ ，すなわち関数構成が系統 的に行え，また，安定領域の拡張につながる新しい項 をもつリアプノフ関数を採用する。

電力系統の動特性式は一般に次式の様な非線形オー トノマス系として記述することができる。

$\dot{x}=f(x), f(0)=0$

ここで, $x: n$ 次元のべクトル関数, $x=0$ :

平衡点

ラグランジィ・シャルピ法によれば, (4)式に対す 
るリアプノフ咸数 $V$ は次式の偏微分方程式を解くこ とによって求められる。

$$
\boldsymbol{F}(\boldsymbol{x}, V, \boldsymbol{P})=\boldsymbol{P}^{T} \boldsymbol{f}(\boldsymbol{x})+\phi(x)=0
$$

ここで, $\boldsymbol{P}=\partial V / \partial x$ てあり， $\phi$ は後に決定さ

れる任意の非負值関数である。

（5）式を解くための特性徽分方程式は

$$
\begin{aligned}
& \frac{d x_{1}}{\partial F / \partial P_{1}}=\frac{d x_{2}}{\partial F / \partial P_{2}}=\cdots=\frac{d x_{n}}{\partial F / \partial P_{n}} \\
& =\frac{d V}{P_{1} \frac{\partial F}{\partial P_{1}}+P_{2} \frac{\partial F}{\partial P_{2}}+\cdots+P_{n} \frac{\partial F}{\partial P_{n}}} \\
& =\frac{-d P_{1}}{\frac{\partial F}{\partial x_{1}}+P_{1} \frac{\partial F}{\partial V}}=\frac{-d P_{2}}{\frac{\partial F}{\partial x_{2}}+P_{2} \frac{\partial F}{\partial V}} \\
& =\cdots=\frac{-d P_{n}}{\frac{\partial F}{\partial x_{n}}+P_{n} \frac{\partial F}{\partial V}} \cdots \cdots \cdots \cdots \cdots
\end{aligned}
$$

て与えられ、このとき $\partial F / \partial x_{1}, \partial F / \partial x_{2}, \cdots, \partial F / \partial x_{n}$ は それぞれ $\partial \phi / \partial x_{1}, \partial \phi / \partial x_{2}, \cdots, \partial \phi / \partial x_{n}$ を含む。

上式より, 少なくともPの一つの成分を含む $n-1$ 個の式

$$
\left.\begin{array}{l}
G_{1}(x, V, P, \partial \phi / \partial x)=0 \\
G_{2}(x, V, P, \partial \phi / \partial x)=0 \\
\cdots \cdots \cdots \cdots \cdots \cdots \cdots \cdots \cdots \\
G_{n-1}(x, V, P, \partial \phi / \partial x)=0
\end{array}\right\}
$$

が运出されるならぱ,この $G$ と（5)式の $F$ が共通解 を有するためには

$$
\left[G_{i}, F\right]=\sum_{k=1}^{n}\left[\frac{d G_{i}}{d x_{k}} \frac{\partial F}{\partial P_{k}}-\frac{d F}{d x_{k}} \frac{\partial G_{i}}{\partial P_{k}}\right]
$$$$
=0
$$

ただし $, i=1,2, \cdots, n-1$

が成立しなければならない。ここで， $\left[G_{i}, F\right]$ が $\boldsymbol{P} の$ 関数ならほ，更に $\left[G_{i}, F\right]=G$ と置き，このすへての $G$ が $F$ と共通解をもつようにする。従って，末知関 数 $\partial \phi / \partial x, \phi$ は次のヤコビの括弧式が零になる条件

$$
\left[G_{p}, G_{q}\right]=\sum_{k=1}^{n}\left[\frac{d G_{p}}{d x_{k}} \frac{\partial G_{q}}{\partial P_{k}}-\frac{d G_{q}}{d x_{k}} \frac{\partial G_{p}}{\partial P_{k}}\right]=0
$$

$$
\left[G_{s}, F\right]=\sum_{k=1}^{n}\left[\frac{d G_{s}}{d x_{k}} \frac{\partial F}{\partial P_{k}}-\frac{d F}{d x_{k}} \frac{\partial G_{s}}{\partial P_{k}}\right]=0
$$

たたし $p, q=1,2, \cdots, \max (s), s>n-1$,

$p \neq q$

を满足し，かつ れる。申はその非負値性の証明の容易さから $x$ に関 する二次形式の項を含むことが望ましいので，[G $G_{i}$, $F]=G$ の置き換えは (9)式の偏微分方程式が $\phi に つ$ いての 2 階偏微分形を含むまで続けられる。

軍学㧞D, 111 券 1 号, 平成 3 年 фが決定されたあと，もし(5)，(7)式から

$$
\boldsymbol{P}=\boldsymbol{P}(\boldsymbol{x}, V)
$$

として求められるならば

$$
P^{T} d x=(\nabla V)^{T} d x
$$

は磧分可能であり，所望のリアプノフ関数 $V$ とその 時間微分 $\dot{V}$ は

$$
\begin{aligned}
& V(x)=\int_{0}^{x} P^{x} d x \\
& \dot{V}(x)=-\phi(x)
\end{aligned}
$$

として与えられる。

上記の手順に従い，（3)式に対するリアプノフ関数 を構成する次式となる。

$$
\begin{aligned}
& V\left(\delta, \omega, \Delta P_{m}\right)=\frac{1}{2}\{\omega+\alpha k(\delta)\}^{2} \\
& +\frac{1}{2} \alpha(1-\alpha) k(\delta)^{2}+\int_{\delta_{0}}^{\delta} h(\delta) d \delta \\
& +2 \sqrt{\alpha(1-\alpha) D / M} \int_{\delta_{0}}^{\delta} \sqrt{h(\delta) k(\delta)} d \delta \\
& +\frac{\alpha D}{2 b}\left[\sqrt{g}\left(\delta-\delta_{0}\right)-\frac{\Delta P_{m}}{\sqrt{g}}\right]^{2} \\
& +\frac{\Delta P_{m}^{2}}{2 g}
\end{aligned}
$$

ただし，

$$
\begin{aligned}
& h(\delta)=D\left\{P_{e}(\delta)-P_{m}\right\} / M \\
& k(\delta)=D\left(\delta-\delta_{0}\right) / M \\
& b=1 / T_{g}, g=K_{g} / T_{g}, 0 \leqq \alpha \leqq 1
\end{aligned}
$$

また，その時間導関数は次式となる。

$$
\begin{gathered}
\dot{V}\left(\delta, \omega, \Delta P_{m}\right)=-\left[\frac{b+\alpha D / M}{g}\right] \Delta P_{m}^{2} \\
-\{\sqrt{\alpha(1-\alpha) D / M} \omega-\sqrt{\alpha h(\delta) k(\delta)}\}^{2}
\end{gathered}
$$

(14)式で示されるリアプノフ関数を安定度評価に用

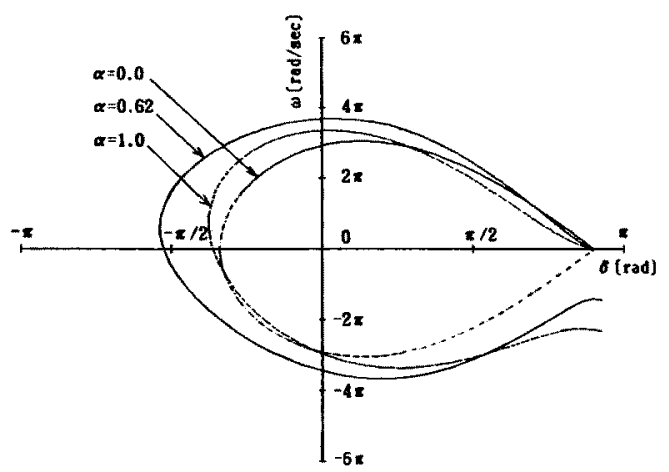

図 8 電力系統の安定領域

Fig. 8. Stability boundary for a power system. 
いるには, 安定限界を与える $V$ の值 $V_{\max }$ を求めな ければならないが，(14)式の $V$ は $\alpha$ の選定により異 なる安定領域を与える。ここでは，V而的最大にな る $\alpha$ ，すなわち， $\alpha=0.62$ を算出し，このときの安定 領域を採用する。参考のため, 図 8 には $\alpha=0.0$ 朽よ び $\alpha=1.0$ の安定領域も示す。なお, 本システムに対 する安定領域は本来, 三次元空間で与えられるべきも

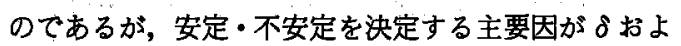
び $\omega$ でることから $\Delta P_{m}=0$ の断面のみを描いてい る。図 8 で示される安定領域内では, リアプノフの安 定定理により漸近安定が保証されていることから, 領 域内を初期值とするシステムの解軌道は, 最終的に安 定平衡点に収束する。それゅえ，故障などが生じたと き解軌道が $V_{\max }$ に到達するまでに適切な処置, すな わち故障回線の遮断を施せばシステムは脱調すること なく安定に至らしめることができる。しかしながら， 実際には,リアプノフ関数を計算するのに必要な処理 時間および遮断器を動作させるのに必要な動作時間の 遅れが存在するので, $V$ が $V_{\max }$ に到達した時点で遮 断信号を出力してもすで解軌道は安定領域外に進 み, 必ずしも安定を保証することはできない。ここで は,リアプノフ関数を計算するのに必要な処理時間お よび遮断器を動作させるのに必要な動作時間の遲れを 補正するため, オイラー法によるリアプノフ関数の予 測値を

$$
V_{(t+T)}=V_{(t)}+\left\{V_{(t)}-V_{(t-N T s)}\right\} T / N T_{s}
$$

で算出し，過渡安定度評価に適用する。上式におい て, $V_{(t)}$ は時刻 $t$ におけるリアプノフ関数の值, $T_{s}$ はサンプリング時間, $T$ はリアプノフ関数を計算す るのに必要な处理時間および遮断器を動作させるのに 必要な動作時間のトータル時間を意味する。なお， $N$ については $T / N T_{s} \fallingdotseq 1$ となるように選ぶ。

\section{3. 結果および考察}

電力系統のオンライン過渡安定度評価システムの有 効性を検証するために，図 2 に示す一機-無限大母線 系統を対象とした計算機シミュレーションおよび実機 モデルの実験結果を比較する。このとき電力系統の運 転条件は, 位相差 $\delta_{0}=0.35 \mathrm{rad}$, 速度 $\omega_{0}=60 \pi \mathrm{rad} / \mathrm{s}$

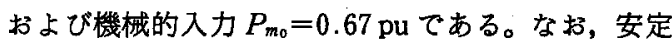
度評価を行うリアプノフ関数としては, ラグランジ ユ・シャルピ法によるリアプノフ関数を採用する。ま

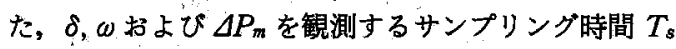
は $4 \mathrm{~ms}$ であり,リアプノフ関数を計算するのに必要

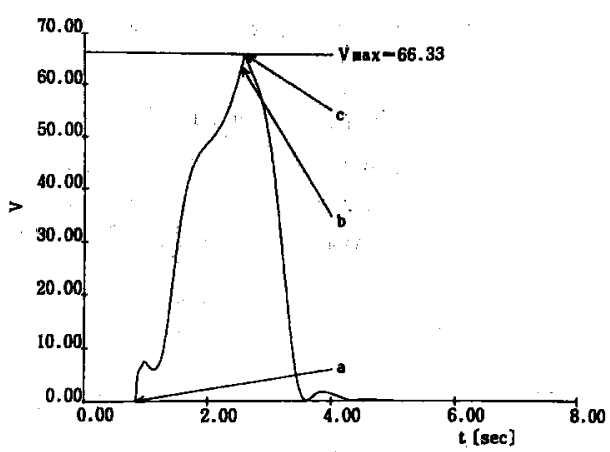

図 9 計算結果による $V-t$ 特性 Fig. 9. $V-t$ characteristic for computer simulation.

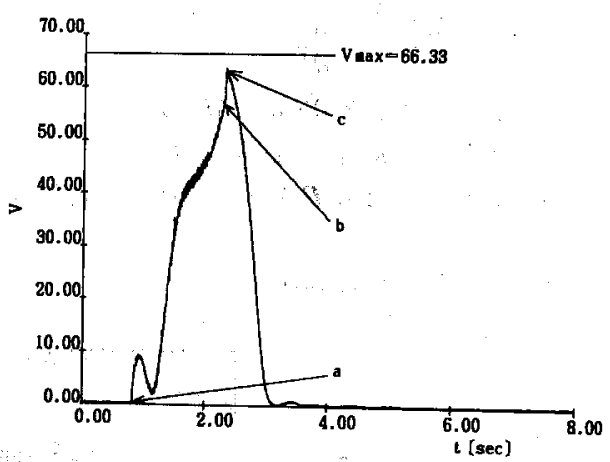

図 10 実験結果による $V-t$ 特性

Fig. 10. $V-t$ characteristic for experimental result.

な処理時間および遮断器を動作させるのに必要な動作

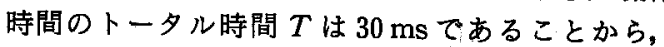

(16)式の $N$ は 8 として実行する。

図 9 および図 10 は, 提案するオンライン過渡安定 度評価システムを用いて二回線送電線の一回線上 $A$ 点に想定した三相短絡故障を除去したときの時間対り アプノフ関数值の計算機シミュレーションと実験結果 とを示したものである。これらの図において， $a$ 点は 三相短絡の故障発生点を, $b$ 点は遮断信号出力点を, また $c$ 点は故障回線の遮断点をそれぞれ示している。 なお，実機モデルでは三相短絡故障が瞬時に起こらな いことから，計算機シミュレーションを行う際にはこ の点を補正するために故障発生瞬時に仮想的負担を考 慮する。同図より明らかなように, 故障発生後, 発電 機の加速とともにリアプノフ関数值 $V$ も上昇し; ま た遮断信号が出力される $b$ 点においても, 前述した ようにリアプノフ関数を計算するのに必要な処理時間 および遮断器を動作させるのに必要な動作時間が存在 


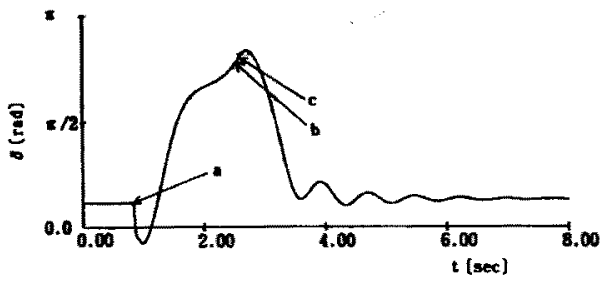

（a）位相差 $\delta 0$ 応答

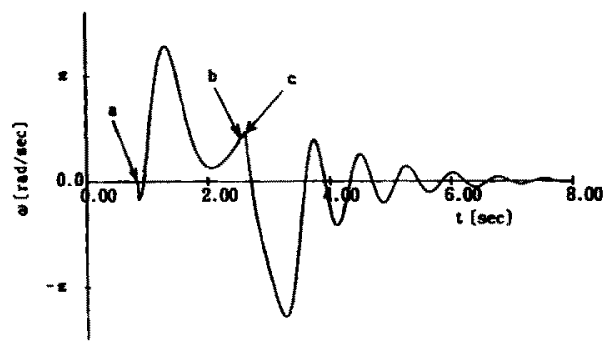

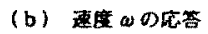

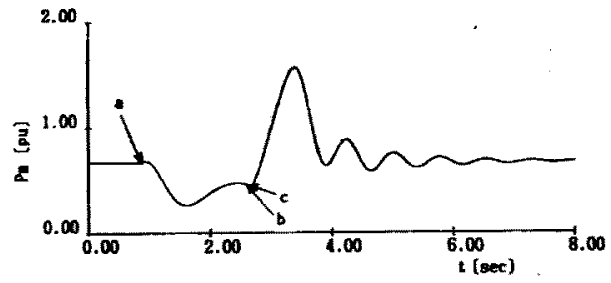

(c) 提的入力 $P$. O衣管

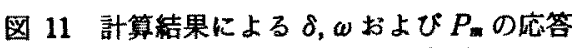

Fig. 11. Responses of $\delta, \omega$ and $P_{m}$ for computer simulation.

するのでVはなお上昇し続けていることが分かる。 しかしながら，c点においては遮断器が実際動作する のて，遮断と同時にVは隇少している。

図 11 およひ同 12 は, 計算機シミュレーションおよ

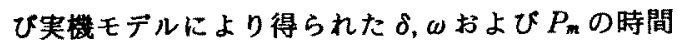
的㚆化を示したものである。これらの結果から明らか なように, 計算機シミュレーションと実機モテルルよ る夷駩結果とで得られた $\delta, \omega$ および $P_{m}$ の時間的変 化は非常によく似た㥧向がある。また, 故障回線除去 後のこれらの波形は, 安定領域内で適切な処置が施さ れているので, 最終的には新しい平衡点へと収束して いくことがわかる。

\section{4.むすび}

本論文ては，故障回線の除去を自動的に行えるオン ライン過度安定度評価システムをラグランジュ・シャ ルピ法に基づくリアプノフ関数を用いて構成した。ま た，本システムの有効性を検証するため $5.5 \mathrm{~kW} の$ 直

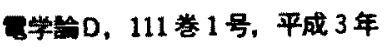

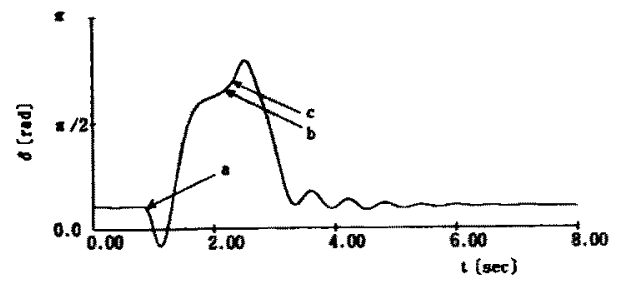

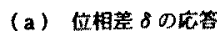

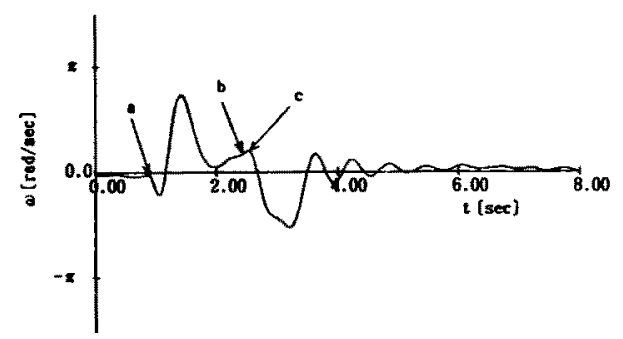

(b) 速度 $\omega$ の底答

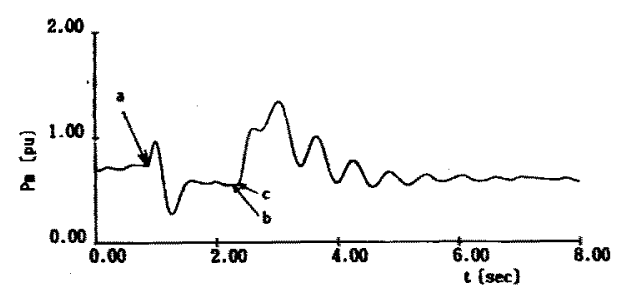

(c) 機槙的入力 $P$. O应管

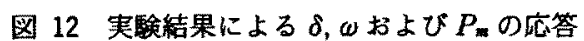
Fig. 12. Responses of $\delta, \omega$ and $P_{m}$ for experimental result.

流電動機およひ $3 \mathrm{~kW}$ の交流発笔機からら構成された模 擬電力システムを対象に計算機シミュレーションと実 機モテルによる実験結果との比較で行った。本論文の 特徵は次の点にある。

（1）リアプノフ関数を評価するのに必要な位相差 測定莣置を構築し，その有効性を検証した。

（2）リアブノフ関数を計算するのに必要な処理時 間㧍よひ遮断器を動作させるのに必要な動作時間の遅 れを補正するため,オイラー法によるリアプノフ関数 の予测法を提案した。

なお，一機無限大母線系統を対象に本手法の有効性 を検証したが，今後，系統負荷の取报いが可能な Bergen らの構造保存モデル(8)/(9) の考元方を多機系統 に適用し，漸近安定領域の拡張につながる非ルーリエ 形リアプノフ関数を堹成し, 多機系統のオンライン過 渡安定度評価システムを構築していきたいと考えて いる。

最後に，本実験に多大な協力をいただいた OCC 
（株）具志幸人氏および日立エンジニアリングサービ ス (株) 瑞慶山薫氏に感謝の意を表します。また，本 研究は文部省科学研究費 (一般研究 C) の助成のもと に行われたことを付記し，併せて謝意を表します。 (平成 2 年 4 月 3 日受付, 同 2 年 7 月 10 日再受付)

(1) G. E. Gless: "Direct method of Lyapunov applied to tran sient power system stability", IEEE Trans Power Apparatus Syst. PAS-85, 159(1966)

(2) A. H. El-Abiad \& K. Nagappan: "Transient stability region of multimachine power systems", ibid., PAS-85, 169(1966)

(3) M. W. Siddiqee: "Transient stability of an a. c. generator by Lyapunov's diredt method", Int. J. Control, 8, 131 (1968)

(4) Y, N. Yu, K, Vongsuriya: "Nonlinear power system stability study by Lyapunov function and Zubov's method" IEEE Trans. Power Aparatus Syst., PAS-86, 1480 (1967)

(5) A. K. De Sarkar, N. Dharma Rao: "Zubov's method and transient-stability problems of power systems", Proc. Instn Elect. Engrs, 118, 1035(1971)

(6) M. A. Pai, M. Anarida Mohan, J.Gopala Rao: "Power system transient stability regions using popov's method", IEEE Trans. Power Apparatus Syst., PAS-89, 788(1970)

( 7 ) H. Miyagi, T. Taniguchi : "Lagrange-Charpit method and stability problem of power systems", IEE Proc., 128, Pt. D, 117(1981)

(8) A. R. Bergen, D. J. Hill: "A Structure preserving model for power system stability analysis", IEEE Trans. Power Apparatus Syst., PAS-100, 25(1981)

(9) D. J. Hill \& A. R. Bergen: "Stability analysis of multima chine power netwoks with linear frequency dependent loads", IEEE Trans. Circuits Syst., CAS-29, 840(1982)

\section{付 録}

諸記号の説明を以下に示す。

$\mathrm{M}$ : 賣性定数

D : 制動係数

$\mathrm{E}_{q}^{\prime}$ : 内部誘起電圧
$E_{b}:$ 無限大母線電圧
$X_{d}^{\prime}$ : 直軸過渡リアクタンス
$\dot{Z}_{1}:$ ：回線の線路インピーダンス
$T_{g}:$ 調速機系時定数
$K_{g}$ 調速機系利得

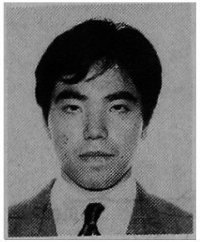

\section{平良栄 吉 (正員)}

昭和 40 年 12 月 12 日生。平成 2 年 3 月琉球大学大学院修士課程修 了。同年 4 月三菱電機 (株) 入社, 現 在に至る。

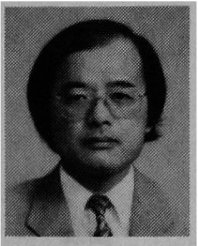

\section{宮 城 草 夫（正員）}

昭和 24 年 2 月 11 日生。 53 年 3 月大阪府立大学大学院博士課程修 了。 52 年琉球大学工学部助手, 57 年同大学工学部助教授, 62 年同大 学工学部教授, 現在に至る。工学博士。主として, シ ステムの安定論に関する研究に従事。

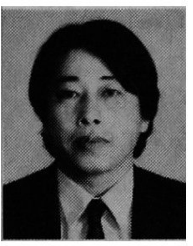

$$
\text { 山下勝已(正員) }
$$

昭和 27 年 2 月 20 日生。 55 年 3 月大阪府立大学大学院博士課程単位 取得修了。57 年琉球大学工学部助 手, 62 年同大学工学部助教授, 現 在に至る。工学博士。'主として, 電力系統の負荷周波 数制御，信号処理に関する研究に従事。 